\title{
実験的潜函病の研究 \\ Experimental Studies on the Caison Disease
}

\author{
東京大学医学部衞生学教室 \\ 豊川行平成瀬定男前田平馬 \\ Kôhei Toyokawa, Sadao Naruse, Heima Maeda \\ Department of Hygiene, Faculty of Medicine, University of Tokyo
}

\begin{abstract}
緒 言
潜函病は高圧下に扝いて生体の組織体液に溶解せる過 剩の窒素が急速減圧時に気泡化し血管に栓塞を生じその 流域の諸組織定障害するととによつて発生する。原因が かくのごとく純物理的作用にあることは周知の事実であ るが, 実験的潜函病の発病, 死亡条件を既往の文献に求め るとかなりの不一致が及られる。すなわち野村 と家鬼で 100 封度 30 分にて発病, 110 封度より 120 封度 30 分にて死亡とし, 清原 ${ }^{21}$ 以 $5.5 \mathrm{~kg} / \mathrm{cm}^{2} 25$ 分より 30 分 で発病, $5.5 \mathrm{~kg} / \mathrm{cm}^{2} 40$ 分で死亡, 上田 ${ }^{3}$ は $5.5 \mathrm{~kg} / \mathrm{cm}^{2}$ 35 分で発病, 同 40 分で死亡, 土屋 ${ }^{4}$ 流 $5.5 \mathrm{~kg} / \mathrm{cm}^{2} 20$ 分 で死亡と報告している。元来潜函病の発生に约個体差が 非常に著明であるこされているが,さらに発病, 死亡に関 係する因子として実験動物の性別, 成熟度, 加減圧時の気 温の変動, 反復使用による耐性の出現な゙゙が考えられる。 われわれはこれらの条件を参考として, 家鬼による実 験的潜函病の発病, 死亡条件を求め, 同時儿その臨床所 見，剖検所見を観察したので報告する。
\end{abstract}

\section{実験設備，実験材料， 実験方法}

1. 実験設備: 再圧治療タンクで, 鋼製主室 ( 2 名収 容可能), 副室に分かれ, 最高使用気圧 $7.0 \mathrm{~kg} / \mathrm{cm}^{2}, 4$ 吋 2 気筒エアコンプレッサー,ディーゼルエンジン 10 馬力, 貯気タンク $\left(10 \mathrm{~kg} / \mathrm{cm}^{2}\right.$ まで貯気可能), 空気冷却用水槽 を備え, 昇圧能力性主室注 $3.0 \mathrm{~kg} / \mathrm{cm}^{2}$ まで 5 分, 4.0 $\mathrm{kg} / \mathrm{cm}^{2}$ まで 8 分, $5.5 \mathrm{~kg} / \mathrm{cm}^{2}$ まで23分 30 秒, 副室は $3.0 \mathrm{~kg} / \mathrm{cm}^{2}$ まで 20 秒, $4.0 \mathrm{~kg} / \mathrm{cm}^{2}$ まで 40 秒, $\quad 5.0$ $\mathrm{kg} / \mathrm{cm}^{2}$ まで5分, $5.5 \mathrm{~kg} / \mathrm{cm}^{2}$ まで 8 分, $6.0 \mathrm{~kg} / \mathrm{cm}^{2}$ まで10分である。高圧になるにつれて, 加減圧時間が比 例以上に增大するが, 空気の漏洩, コンプレッサーの能 力などによるものである。減圧時間は排気弁の全開で 2
分である。

2. 実験動物: 体重 $2.5 \mathrm{~kg}$ 前後の成熟家鬼で, 実験 前一定期間 1 匹につきオリェンタル醳母株式会社製固型 飼料（R C 5）1日 $120 \mathrm{~g}$, 水 1 日 $200 \mathrm{cc}$ 亿て飼育した ものを使用。

3. 実験方法 : 再圧治寮タンクの副室老用い希望高圧 まで10分前後で加圧するようにし, 一定時間滞在後前記 の方法で急速減圧し潜函病発症の有無を調べた。家鬼は 自由に運動できるが，激しい運動のできない鉄製檻に入 れて実験を抢てなつた。な扮実験前 4 時間は䬣を与え ず, また疲労, 馿化など高圧による影響を防ぐため, 毎 回異なつた家鬼を使用した。

\section{実験成績}

われわれは清原 ${ }^{2}$, 上田 ${ }^{31}$ の未発症条件 $5.5 \mathrm{~kg} / \mathrm{cm}^{2}$ 滞在 15 分, 加圧 3 分 40 秒, 減圧 1 分に近い条件, 寸なわ方 5.5 $\mathrm{kg} / \mathrm{cm}^{2}$ 滞在 15 分, 加圧 8 分, 減圧 2 分で白色雌性家鬼 2 匹を用いて実験したが,いずれも重症潜函病に罹患, 発病 した。ついで気圧を $1.0 \mathrm{~kg} / \mathrm{cm}^{2}$ 低くして, $4.5 \mathrm{~kg} / \mathrm{cm}^{2}$ 加 圧 2 分 30 秒, 滞在 20 分, 減圧 1 分 20 秒で 2 匹につき実験 し, 未発症のため以後高圧条件 は $5.0 \mathrm{~kg} / \mathrm{cm}^{2}$ 以上とし 計30匹について実験した。その成績は第 1 表のごとくで ある。すなわち雄性家鬼21匹, 雌性家乘 9 匹で, 雄性家鬼 は $5.5 \mathrm{~kg} / \mathrm{cm}^{2}$ 滞在 25 分, 加圧 8 分, 減圧 2 分では $2 / 3$, $5.6 \mathrm{~kg} / \mathrm{cm}^{2}$ 滞在 20 分では $2 / 2$ 死亡, $5.0 \mathrm{~kg} / \mathrm{cm}^{2}$ 滞在 20 分, 加圧 5 分, 減圧 2 分では10匹全例に, $4.5 \mathrm{~kg} / \mathrm{cm}^{2}$ 滞在 20 分, 加圧 2 分 30 秒, 減圧 1 分 20 秒では 2 匹全例に発病を 認內なかつた。雌性家鬼では $5.5 \mathrm{~kg} / \mathrm{cm}^{2}$ 滞在 20 分, 加圧 5 分, 減圧 2 分で $1 / 7$ 発病, $4 / 7$ 死亡がみられ, $5.5 \mathrm{~kg} / \mathrm{cm}^{2}$ 滞在 15 分, 加圧 8 分, 減圧 2 分では ${ }^{2} / 2$ の死亡であつた。 すなわち本実験では発病, 死亡条件のそれぞれを明確に 区別しらるものは得られなかつた。 
第 1 表急速減圧実験成 縤

\begin{tabular}{|c|c|c|c|c|c|c|c|c|c|c|c|}
\hline 番号 & 性別 & 体 $\mathrm{kg}^{\text {重 }}$ & 種 別 & $\begin{array}{l}\text { 高 压 } \\
\mathrm{kg} / \mathrm{cm}^{2}\end{array}$ & $|\underset{\text { 分 }}{\mid \text { 加压時間 }}|$ & $\begin{array}{l}\text { 滞在時間 } \\
\text { 分 }\end{array}$ & $\mid \begin{array}{c}\text { 減圧時間 } \\
\text { 分 }\end{array}$ & タンク & $\begin{array}{l}{ }^{\circ} \mathrm{C} \text { 温度 } \\
\end{array}$ & 経 & 過 \\
\hline 1 & ㅇ & 3.5 & 白 & 5.5 & 8 & 15 & 2 & 22 & $\sim-1$ & 15分後死亡 & \\
\hline 2 & $\hat{o}$ & 3.2 & 黒 & 4.5 & 2.5 & 20 & 1 & 21 & $\sim 4$ & 健 & \\
\hline 3 & $\hat{\delta}$ & 3.3 & 白 & 4.5 & 2.5 & 20 & 1 & 21 & $\sim 4$ & 健 & \\
\hline 4 & 우 & 3.3 & 白 & 5.5 & 8 & 15 & 2 & 24 & $\sim 4$ & 20分後死亡 & \\
\hline 5 & $\delta$ & 3.4 & 白 & 5.0 & 5 & 15 & 2 & 22 & $\sim 4$ & 健 & \\
\hline 6 & q & 3.4 & 灰白斑 & 5.0 & 5 & 20 & 2 & 22 & $\sim 0$ & 20分後後肢麻瘏 & \\
\hline 7 & $\hat{o}$ & 3.4 & 白 & 5.0 & 5 & 20 & 2 & 23 & $\sim 2$ & 健 & \\
\hline 8 & ㅇ & 2.65 & 白 & 5.0 & 5 & 20 & 2 & 26.5 & $5 \sim 6$ & 5 分後死亡 & \\
\hline 9 & $\hat{o}$ & 2.55 & 白 & 5.0 & 5 & 20 & 2 & 22 & $\sim 0$ & 健 & \\
\hline 10 & 우요 & 3.6 & 白 & 5.0 & 5 & 20 & 2 & 20 & $\sim 0$ & 5 分後死亡 & \\
\hline 11 & 우 & 3.6 & 白 & 5.0 & 5 & 20 & 2 & 20 & $\sim 3$ & 8 分後死亡 & \\
\hline 12 & 우 & 2.45 & 黒 & 5.0 & 5 & 20 & 2 & 27 & $\sim 8$ & 健 & \\
\hline 13 & $\hat{\delta}$ & 2.85 & . 白 & 5.0 & 5 & 25 & 2 & 23 & $\sim 8$ & 健 & \\
\hline 14 & ㅇ & 2.3 & 白 & 5.0 & 5 & 20 & 2 & 26.5 & $5 \sim 8$ & 11分後死亡 & \\
\hline 15 & 우 & 2.9 & 白 & 5.0 & 5 & 20 & 2 & 27 & $\sim 6$ & 健 & \\
\hline 16 & $\hat{o}$ & 2.4 & 白 & 5.0 & 5 & 25 & 2 & 23 & $\sim 5.5$ & 健 & \\
\hline 17 & $\hat{o}$ & 2.6 & 白 & 5.5 & 8 & 25 & 2 & 25 & $\sim 6$ & 健 & \\
\hline 18 & $\hat{o}$ & 3.6 & 白 & 5.5 & 8 & 25 & 2 & 26 & $\sim 5$ & 10分後死亡 & \\
\hline 19 & $\delta$ & 3.5 & 黒 & 5.5 & 8 & 25 & 2 & 24 & $\sim 5$ & 5 分後死亡 & \\
\hline 20 & $\hat{o}$ & 3.6 & 白 & 5.5 & 8 & 20 & 2 & 23 & $\sim 4$ & 健 & \\
\hline 21 & $\hat{o}$ & 2.4 & 白 & 5.5 & 8 & 20 & 2 & 21 & $\sim 4$ & 健 & \\
\hline 22 & $\hat{o}$ & 2.9 & 白 & 5.6 & 9 & 20 & 2 & 26 & $\sim 4$ & 5 分後死亡 & \\
\hline 23 & $\hat{\delta}$ & 1.7 & 灰 & 5.5 & 8 & 20 & 2 & 24 & $\sim 3$ & 健 & \\
\hline 24 & $\hat{\delta}$ & 3.65 & 白 & 5.5 & 8 & 20 & 2 & 28 & $\sim 10$ & 健 & \\
\hline 25 & $\hat{\delta}$ & 2.9 & 白 & 5.6 & 9 & 20 & 2 & 32 & $\sim 12.5$ & 30 分後死亡 & \\
\hline 26 & $\hat{o}$ & 2.1 & 白 & 5.5 & 8 & 20 & 2 & 28 & $\sim 9.5$ & 健 & \\
\hline 27 & $\hat{o}$ & 2.25 & 白 & 5.5 & 8 & 20 & 2 & 24 & $\sim 5$ & 健 & \\
\hline 28 & $\hat{o}$ & 2.3 & 白 & 5.5 & 8 & 20 & 2 & 28 & $\sim 7$ & 健 & \\
\hline 29 & $\hat{o}$ & 3.1 & 白 & 5.5 & 8 & 20 & 2 & 25 & $\sim 5$ & 健 & \\
\hline 30 & $\hat{\delta}$ & 1.7 & 黒 & 5.5 & 8 & 20 & 2 & 24 & $\sim 5$ & 健 & \\
\hline
\end{tabular}

減圧後発病, 死亡に至る時間注最短 5 分, 最長 30 分て 10分前後の死亡が多数であつた。

なおタンク内温度の変動は非常に著しく, 加圧前 $12^{\circ} \mathrm{C}$

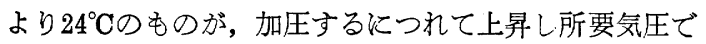
は $20^{\circ} \mathrm{C}$ より $30^{\circ} \mathrm{C}$ 前後となり, 減圧時に注一 $1^{\circ} \mathrm{C}$ より $12^{\circ} \mathrm{C}$ へと平均 $13^{\circ} \mathrm{C}$ の降を示した。

潜函病発病家鬼の臨床所見：No. 6 が発病したがその 所見は従来の報告とまつたく同様で, 復圧直後にはなん ら異常なく20分後より両後肢に弛緩性麻瘏が出現し, 後 肢を引きずるような歩行を示し, かつ糞尿失禁を認め, 再圧治療により後肢麻疩は治癒し翌日常態に復した。

剖検所見:死亡せる10例について形のごとく扢てない
従来の報告と類似の所見であつたが, 特異と思われる点 を述べると, A. 心: 冠血管内にガス泡の羅列, 心室内 にガス泡沫を含有せる血液あり，ととに右室に著明。B． 胃: 胃体部执いては小円形の点状出血性糜爛が粘膜翻 譬の頂点にあり，かつ胃周囲血管にガス泡の羅列を認め る。No. 14では大彎部噴門近くに充血捛よび粘膜解璧頂 点の出血性麼爛があり,かつ小腸粘膜の充血あり。No. 18 では大彎前壁に出血斑, No. 22では十二指腸に糜爛点状 出血, No. 25 では大彎後壁糜爛, 十二指腸糜爛を認める。 C. 副腎 : 点状出血を認める。D. 肝および腎 : 表面に 点状出血斑怙よび腎杯部に出血線を認さ。かくのごとく 潜函病にて死亡せる場合は単に気泡の栓塞による血流阻 
止のみならず, 各重要臟器の出血ならびに胃の糜爛が認 められ,生体全般の諸機能の廃絶の进大さが想像される。 尔た潜函病を発症しなくても各臓器に気泡が発生する。 梨本 ${ }^{51}$ 快急速減圧による肝組織内気泡の発生を, 先た Gersh 注減圧にる副腎皮質内気泡の発生を報告して いる。

\section{粉括, 考案}

われわれ注30匹の成熟家鬼について各種高圧条件を負 荷し前記の結果学得た。乙れを既往の文献に文られる諸 成績と比較検討する化, まず既往に括いて発病, 死亡と性 別の関係について言及せるもの变々れない。しかし野 村1) の実験結果で坆病, 死亡の29例中, 雌性柱19例, 雄 性 6 例で同一条件に括いて性らかに前者昛発病, 死亡 の多いことがうかがわれた。われわれの実験においても 雌性没雄性に比して低い条件下, 寸なわち $5.5 \mathrm{~kg} / \mathrm{cm}^{2}$ 15分では $100 \% ， \quad 5.0 \mathrm{~kg} / \mathrm{cm}^{2} 20$ 分では70\%の死亡がみ られ，乙れらの点より雌性家鬼注雄性家雨に比し高王耐 性が低いといえよう。次にわれわれの得た実験結果で 性, 雄性家鬼の死亡条件は $5.5 \mathrm{~kg} / \mathrm{cm}^{2}$ 25分, あるいは $5.6 \mathrm{~kg} / \mathrm{cm}^{2} 20$ 分滞在後 2 分で減圧することであり, と の条件注従来の成績 ${ }^{2)}$ (1) 比し低い上引思われるが, 加圧時間の $1 / 2$ を上田の述べるごとく加算すると大体類 似の成績となる。野村 ${ }^{11}$ の条件とわれわれのものとでは 約 $2.0 \mathrm{~kg} / \mathrm{cm}^{2}$ の差があり，一見理解に苦しむところで あるが, 野村の実験では同一家鬼を反復使用, 幼若成熟, 雌雄の区別についての考虑がはらわれていない点, われ われの結果との比較被妥当ではないと考元られる。次に
死亡例の体重老灭ると，5 例は $2.9 \mathrm{~kg}$ 以下であり，6 例活 $3.0 \mathrm{~kg}$ より $3.6 \mathrm{~kg}$ までの肥满せる家鬼で, 体重 差が発病, 死亡左右する重要因子と敒考えられない。

\section{結 論}

われわれは家鬼による実験的潜函病の発病，死亡条件 を求为次の結論を得た。

1）雄性家鬼は此性家鬼に比して高圧ょりの急速減圧 に対する抵抗性が強い。

2）体重と発病，死亡との間注とくに関係が認めら れない。

3）発病, 死亡条件は雙雄別に次のごとくである。

a. 雄性成熟家鬼： $5.6 \mathrm{~kg} / \mathrm{cm}^{2} 20$ 分

$5.5 \mathrm{~kg} / \mathrm{cm}^{2} 25$ 分

b. 雌性成熟家鬼： $5.5 \mathrm{~kg} / \mathrm{cm}^{2} 15$ 分

$5.0 \mathrm{~kg} / \mathrm{cm}^{2} 20$ 分

本論交の要旨は昭和 34 年 3 月第 29 回日本衞生学会総 会飞扣いて発表した。

\section{交献}

1）野村守：海軍々医会雑誌，18，188，1929.

2）清原蕃郷 : 海軍々医会雑誌, 30, 585, 1941.

3) 上田喜一: 慶応医学, 25, 31, 1948.

4) 土屋健三郎 : 慶応医学, 28, 259, 1951.

5) 梨本一郎: 労㗢科学, $31,249,1955$.

6) Isidor Gersh : Decompression Sickness, p. 177. (受付 : 1959 年 7 月 15 日, 特別揭載) 